Милка В. Николић*

Универзитет у Крагујевцу

Филолошко-уметнички факултет

Катедра за српски језик

\title{
СТИЛИСТИЧКЕ КАРАКТЕРИСТИКЕ ЗБИРКЕ ПРИПОВЕДАКА ДЕЦА ИВА АНДРИЋА У КОНТЕКСТУ КЊИЖЕВНОСТИ ЗА ДЕЦУ
}

У овом раду се испитују језичко-стилски поступци у збирци Деца Ива Андрића. Лингвостилистичка анализа показује: (1) да су микродискурси у приповеткама изразито смисаоно уоквирени и да функционишу као уже композиционе целине; (2) да се компактност микродискурса постиже на плану реченице и пасуса. Заступљени су следећи типови стилема: (1) синтаксостилеми (осамостаљивање, интензификација); (2) семантостилеми са формом координативне конструкције (антитеза, таутологија, кумулација); (3) текстостилеми (фигуре смисаоне дискурсне целине; фигуре засноване на амплификативним десцедентним конекторима; понављања). Посматрана као целина, збирка Деца обликује јединствену и поливалентну слику дечјег сазревања. Андрић је успео да створи универзалну причу о детињству у завичају.

Къучне речи: Иво Андрић, збирка приповедака Деца, књижевност за децу, језичко-стилски поступци, композиционе целине.

* milkanik75@gmail.com

** Овај рад написан је у оквиру пројекта Динамика структура савременог српског језика (2011-2019), број 178014, који финансира Министарство науке и просвете Републике Србије. 


\section{1. Увод}

Збирка приповедака Деца Ива Андрића под овим насловом појавила се у његовим сабраним делима 1963. године. Поставља се питање: Да ли су ово приче за децу или приче о детињству намењене одраслима?

Проучаваоци историје књижевности за децу укључују Андрића у прегледе развоја српске дечје књижевности (уп. Милинковић 2014: 208-216; Петровић, Милинковић 2007: 81-88). Међутим, указује се на особеност његовог приповедног стваралаштва са темом детињства: „Очигледно, писац је разбијајући илузију детињства као слике раја за којим ваља жалити, желео да створи реалну слику света у којем деца полако, а можда и прерано откривају право лице живота” (Милинковић 2014: 216). Сматра се „да је Андрићева поетика детињства првим својим сазвучјима и за децу и за одрасле, а другим она је за одрасле и њихово уосећавање у дечји свет" (Башчаревић 2008: 284).

Предмет интересовања у овом раду јесу стилистичке одлике приповедака у збирци Деца, а ово Андрићево остварење сагледава се као целина обједињена темом одрастања. ${ }^{3}$ Циљ истраживања јесте да се испита: (1) који језичко-стилски поступци обједињују збирку; (2) има ли стилистичких разлика у приповеткама.

\section{2. Андрићева збирка Деца у контексту књижевности за децу}

Приповетке у збирци Деца поређане су у складу са хронологијом одрастања и сазревања, дакле, не

3 У старијим лингвистичким истраживањима, Андрићев језик описује се као „класичан” књижевни језик (уп. Јовић 1975: 84; Станојчић 1967: 295). У новијим истраживањима пажња се посвећује експресивној синтакси (в. Николић 2012; Петковић 2011; Степанов 2011), као и наратолошким аспектима Андрићевог стваралаштва (в. Бабић 2012). 
прате редослед објављивања. Приповетка Кула је прва у збирци, а најкасније је објављена (1960); приповетка Деца је најраније објављена (1935), а налази се на четвртом месту у књизи.

Посматране у контексту књижевности за децу, приповетке у збирци Деца знатно се разликују:

(a) Приповетке Кула и Деца најближе су дечјој књижевности јер обрађују тему о дечјим дружинама и приказују свет виђен очима детета. Исто тако, приповетке Прозор и Книга посвећене су догађајима типичним за детињство. Приповетке У завади са светом и Мила и Прелаи, осветљавају проблеме са којима се дете среће током одрастања.

(б) Од књижевности за децу највише се удаљава приповетка Писмо из 1920. године. Збирку затвара приповетка Аска и вук, која се може посматрати као дело за најмлађе читаоце, а по својој симболици и изван дечје књижевности.

(в) Већи део збирке исприповедан је из перспективе дечака или младића. Посебну групу чине приповетке Змија и Ескурзија јер су остварене из перспективе јунакиња. Њима се може прикључити и приповетка На обали, која је једним делом посвећена унурашњем свету девојчице.

Издвајају се следеће одлике Андрићевих приповедака о детињству (в. Ђукић-Перишић 2012: 110-118):

(a) Детињство није приказано као доба безбрижности и среће. Догаћаји из детињства заувек остају у свести човека - наратор у завршници приче Прозор каже: „Целог века се после лечимо од тог детињства”.

(б) Губитак илузије и суочавање са реалношћу која је лишена тајне представља почетак сазревања и одрастања. Ступање у зрело доба подразумева континуитет у преиспитивању, трпљењу, стрепњи.

(в) Јунаци нису индивидуализовани ни профилисани као целовити карактери, већ су у извесном 
смислу само носиоци пишчеве идеје о детињству као добу посртања, страха и лутања. Дечаци-јунаци као да су скупљени у један имагинарни лик који се мултипликује у различитим приповеткама.

Посматрана као целина, збирка Деца може се схватити као прича о одрастању у завичају. Андрићев ужи завичај је „вишеградска стаза”, а шири „босанска стаза”. Како изгледа свет завичаја у очима дечака? То је још увек недовољно осветљен и сужен простор, везан за игру и најближе окружење. Међутим, у очима младића тај свет је јасно осветљен, без улепшавања, а боје су му тамне и непријатне.

3. Језичко-стилске одлике Андрићеве збирке Деца

\section{1. Стилистичке доминанте}

Лингвостилистичка анализа приповедака у збирци Деца показује: (1) да су микродискурси у приповеткама изразито смисаоно уоквирени и да функционишу као уже композиционе целине; (2) да се компактност микродискурса (тј. композиционих целина) постиже на плану реченице и пасуса. Писац посебну пажњу посвећује интонационом обликовању реченице и интеграцији текстовних сегмената у целину, што је општа карактеристика његових приповедних дела. Андрићева приповедна проза има следеће језичко-стилске одлике (в. Ковачевић 2013: 31):

(a) Реченица је „интонационо савршено обликована, са изразитом синтаксичко-семантичком условљеношћу компонената";

(б) Сваки реченични или текстовни део „своју 
вриједност добија тек захваљујући партиципаторској улози" у формирању целине;

(в) Реченица „и кад има ситуационо наративну подлогу - по правилу [jе] или дескриптивно-наративна или рефлексивно-наративна".

Размотрићемо типове стилема који представљају стилистичке доминанте у збирци Деца. ${ }^{4}$ Најфреквентнији су језичко-стилски поступци на реченичном и текстовном плану - којима писац интонационо обликује реченицу и интегрише текстовне сегменте. Анализа показује да различити типови стилема (синтаксостилеми, семантостилеми, текстостилеми) често интерферирају у истом исказу или пасусу.

\subsection{1. Синтаксостилеми и семантостилеми}

Стилематички поступци осамостаљивања спадају међу најфреквентније у збирци, а остварени су уношењем експресивне паузе и распоређивањем осамостаљеног реченичног члана у финалну позицију исказа.

Интонационо издвајање у тексту је обележено следећим знацима:

(a) Запета:

И шапутао би, заиста, све познате молитве, нечујдо, дуго и усрдно (Книга, 69).

Та срећа од тетка-Миле била је стална и свакодневна, као игра, као хлеб, као светлост и сан, али дечак је долазио у године кад су и друге ствари изван њеног круга почињале да га занимају и привлаче (Мила и Прелаи, 26).

4 Сви језичко-стилски поступци које помињемо у овом раду објашњени су у лингвистичкој литератури: Бабић 2002; Бабић 2008; Ковачевић 1998: 63-72; Ковачевић 20156: 125-134; 181-199; 295-345. Појмове дискурс и текст схватамо као у: Ковачевић 2015 а. 


\section{(б) Црта:}

Често би склопила очи и савила се у углу широког канабета, као да спава, и тако вребала сваки покрет и сваку реч, настојећи да једном разабере шта се то плете између њених родитеља, желећи живо и дубоко да јој не измакне ништа од свађе, ако до ње дође, и још дубље и живље - да до не не дође (На обали, 95).

Бежао је - напред. Ни сабље ни барјака, ни другова око њега, ни стварног непријатеља пред њим [...] (Кула, 10).

(в) Двотачка:

Не, најбоље би било и најсигурније: умрети (Кюига, 70).

А на зиду је и даље лежало кратко и непомично Ћорканово тело, смирено и избављено, ослобођено заувек највећег од свих зала људских: поновног буђена (Мила и Преали, 32).

\section{(г) Тачка:}

Није му жао што се опробао, иако осећа да испит није сјајно положио, али је сигуран да пробу не би никад више поновио. Исто као што је решен да о свему овом нипошто не говори. Никад, ником, ниита! (Кула, 12).

Посебан вид осамостаљивања представља уметање делова исказа (парентеза), што се обележава цртом или заградом:

И све је то ограђено и прикривено - као челичним крововима и зидовима - обзирима и конвенцијама једне аустријске чиновничке породице, и законима нераскидивог и неприкосновеног, у католичкој цркви заувек склопљеног брака (На обали, 92).

У једном тренутку ушла је у кухињу тетка Мила. (По гласу је познаје.) Прошла је сасвим близу поред њега (У завади са светом, 22). 
Додатни ефекат се постиже унутарреченичном екскламацијом:

Или ће се десити оно нешто - он сам не зна шта! - што се, по његовом нејасном сазнању, дешава између жена и мушкараца, а чему он не зна имена и не сме и не уме да замисли облик (Кула, 13).

У живој жељи да не прекинем посве и завазда ту везу, да ми бар нешто остане од ње (бар илузија: да ми је нешто остало!), питам је како се зове (Панорама, 130).

Међу стилематичким поступцима који утичу на интонацију реченице велику заступљеност има интензивирање, остварено употребом интензификатора испред члана/чланова синтаксичке конструкције - која може бити:

\section{(a) Клауза:}

Спавала је и Олга, али очигледно друкчијим сном (Екскурзuja, 167).

Осећај гневног гађења изазивао је у њему потребу да кида са свима, да бежи, да умре али далеко негде (Мила и Прелаи, 42).

(б) Субординативна конструкција:

Занимали си га људи, нарочито нови, необични и непознати (Мила и Преали, 27).

(в) Координативна конструкција:

Овако, то су била нестална и неједнака таласања неких мучних осећања, у којима је било $\boldsymbol{u}$ затишја $\boldsymbol{u}$ заборава $\boldsymbol{u}$ веселих дана непомућеног задовольства и мирень са родителима и са иелим светом (На обали, 95).

Никад није била светла ни здрава ни чврста ни лепа (На обали, 84). 
Посебан вид интензивирања представљају палилошка понављања:

(a) Контактно редуплицирање хомоформне језичке јединице (епизеукса):

И то је болело, болело, страховито, изнад сваког очекивања (Кула, 9).

А како стоји ствар уистину, кад се одбаце веровања и формуле које су одавно изгубиле садржину, и речи, речи, речи, које никад нису казивале много, а које данас не значе ништа? (На обали, 84).

(б) Редуплицирање које се остварује тако што се једна јединица понавља у контактно распоређеној јединици са сложенијом синтаксичком структуром (епаналепса):

[...] само тама, зидови и тескоба, задах свакојаког измета, трулежи и влаге, $u$ - страх, безразложни, свемоћни страх, који га засипа хладном језом по леђима (Кула, 11).

Или то није прави пољубаи, полубаи из песама $и$ нејасних слутюи, или можда пољупци не дају оно што у песмама и слутњама обећавају? (На обали, 102)

Ефекат се појачава помоћу интензификатора:

Исти је и изменьен је; $\boldsymbol{u}$ то изменьен у основу, потпуно и заувек (Панорама, 145-146).

Један тип интензификације настаје експлицирањем предлога испред свих именичких јединица које следе иза првог члана напоредне конструкције:

И тада је, у жељи да се склони и сакрије, одтетурао до оних ормана у зиду које зову мусандре и у које се преко дана стављају душеци и постељина, отворио ишарана врата, забио главу у савијен душек и плакао горко од стида, од 
гнева, од тьубави, од тьубоморе, од непознатог бола дечачкога (Мила и Прелаи, 43).

У збирци Деца велику заступљеност имају напоредне конструкције, које Андрић на различите начине трансформише у стилски маркиране. Један од начина јесте формирање синтаксостилема (осамостаљивање, интензификација), а други је формирање семантостилема. Начин на који се постиже стилогеност напоредних низова зависи од броја чланова. У том смислу, постоји разлика између двочланих и вишечланих напоредних конструкција. Доминирају саставне конструкције.

Један део бинарних напоредних конструкција јавља се без изразитих онеобичавања на значењском плану, али са онеобичавањима на формалном плану, која се најчешће постижу:

(a) Навођењем двеју или више двочланих конструкција у исказу:

Као у свакој борби, и ту је било привржености и храбрости, колебана и неверства, суза, крви, издаје и заклетви (Дец, $а, 45)$.

Нешто као подвиг и награда у исто време, као да су те одувек познате ствари са обале, игра и песма, вода и магла, песак и лишће, дан и ноћ, одједном престале да буду расплинуте, безмерне и опште [...] (На обали, 99).

(б) Употребом интензификатора:

Ми остали смо били војска, нестална и недисииплинована, али борбена и грлата (Деца, 45).

(в) Понављањем односно експлицирањем јединица које у стилски неутралној варијанти исказа остају елидиране: 
Њен редак осмејак и юен глас из груди испуњавали су га срећом и радошћу док су трајали, и тугом и зловолом чим их не би видео ни чуо (Мила и Прелаи, 25).

У другу групу спадају бинарне конструкција са семантичким одступањима:

(a) Са координираним антонимима (антитеза):

Чинило му се да је решење свих тих питања код Ђорија, којег никад није волео, који му је и сада одвратан, али који му одједном изгледа и већи и много старији, некако узвишен, достојан и жальена и дивтеньа (Кула, 13).

Нешто као подвиг и награда у исто време, као да су те одувек познате ствари са обале [...] добиле одређен вид и стале да се називају Розиним и његови именом. Депо и страшно. И више страшно него лепо (На обали, 99).

(б) Са координираним референтним синонимима (кумулација):

Све је одједном збрисано и заборавтьено (Кюига, 76).

Жена је венула и опадала као да тоне у земљу (Панорама, 142).

[...] или се, како му његов страх стално дошаптава, одједном претворио у неке безумно испреплетене кривине и спирале које и немају краја ни исхода, и у којима га негде чека сигурна, грозна смрт од страха, исцрпљености и безнађа (Кула, 11).

(в) Ређе са координираним синонимима (таутологија):

Изгледало му је да се одједном и без прелаза нашао у туђем, опасном свету, да је већ одавно далеко од свега што му је блиско и познато (Кула, 10). 
Код вишечланих напоредних конструкција постоје следећи типови:

(a) Набрајање синтаксичких јединица између којих нема семантичких преклапања (синатроизам):

Ћоркан, који је тридесетак година вршио у касаби безимени занат хамала, свирача, севдалије, пијанице и свачијег слуге (Мила и Прелаи, 28).

Ветрови, кише, снегови, туди и животиюе уништавали су и разносили све што није од камена [...] (Кула, 7).

(б) Набрајање референтних синонима (кумулација):

Ocећао се тежак, мрачан и уклет, чувар неке ужасне тајне [...] (Мила и Прелаи, 39).

Све друго је давно прекужено, прошло, заборавльено (Мила и Прелаи, 43).

(в) Набрајање значењски различитих јединица испред којих је синсемантички катафорички пилон:

Према свему ономе што је начуо, замишљао је да то мора бити некако овако: човек живи, једе, пије, спава, иде улицама и свршава послове, у свему изгледа као и остали (У завади са светом, 18).

Посебну групу семантостилема представљају конструкције код којих се значење једне јединице прецизира другом која има исти денотат (епанотроза):

Тако је коректни и отмени брачни пар Калина - у ствари двоје сувих, мрачних и бродоломних тьуди - дошао у касабу и ту се настанио [...] (На обали, 89).

И када се јављају без семантичких онеобичавања, напоредне конструкције доприносе стилизацији исказа 
на интонационом и смисаоном плану. Као што показују наведени одломци, понекад су у оквиру вишечланих низова саставним везником повезани поједини чланови тако да чине парове, а често се у истом исказу јављају и вишечлане и бинарне напоредне конструкције.

Посебну групу семантостилема представљају семантичка понављања која не захтевају одређену синтаксичку форму:

(a) Понављање синонимних лексема (стилска фигура синонимија):

У белој и узвиситој кући, окруженој воћњаком, у којој је живео инспектор Калина са породицом, владао је - пакао; један од оних породичних инферна у којима двоје супружника, као осућеници, избезумљени од мржње, вуку исто уже, свако на своју страну [...] (На обали, 91-92).

(б) Понављање синонимних јединица које припадају различитим нивоима хијерархије (епимоном):

Изгледало му је да се одједном и без прелаза нашао у туђем, опасном свету, да је већ одавно далеко од свега што му је блиско и познато (Кула, 10).

(в) Понављање синонимних клауза (метабола):

Негде у дну те светле среће био је један таман тон: страх $\partial a$ она пролази и да јој се ближи крај (Панорама, 123).

У збирци Деца мање су заступљене фигуре засноване на семантичким понављањима изван напоредне конструкције. То показују наведени примери епимонома и метаболе, који су у форми напоредне конструкције, тако да се могу посматрати као таутологија. 


\subsection{2. Текстостилеми}

На текстовном плану, стилистичку доминанту у збирци Деца представљају фигуре понављања. Најфреквентнија су позиционо неусловљена понављања:

(a) Нехомоформних јединица (полиптотон):

Девојка је слушала стварни говор стварног човека са неодређеним изгледом (Екскурзија, 169).

Та кућица је наслеђена од мајчиног деде али као што се наслеђује болест (На обали, 84).

(б) Хомоформних јединица (епаналепса):

И поздраве се људи са њим, немо, у пролазу, али се нико не задржава, нико му не долази и нико га не зове, осим ако баш не може друкчије (У завади са светом, 18).

Сиротиға је она, као што су сиротиға њени становници, [...] (На обали, 85).

Ефекат се појачава комбиновањем полиптотона и епаналепсе:

Шала данас, щала сутра; смеју се газде, пије и кличе Ћоркан, али, најпосле, све се шале остварују и на крају сваке шале је смрт и иза сваког смеха ћутање (Мила и Прелаи, 31). Некад $y$ сну, некад у музиии, а понекад усред бела дана, у тренуцима кад се налази, бар наизглед подједнако далеко и од сна и од музике (Кула, 14).

У збирци Деца мање су заступљена позиционо условљена понављања хомоформних јединица:

(a) Анафора: 
Немогућно је било заборавити оно што је видео и чуо. Немогућно је било ма коме казати и исто тако немогућно носити у себи неказано и необјашњено као ужас и спствену кривицу (Мила и Прелаи, 38).

\section{(a) Епифора:}

Двориште засађено цвећем без много реда и богатог избора, сиротиғски. Цела кућа је бела, окречена од стрехе до темеља, а „сокл” је назначен плавом бојом, невеселом и посном, нестваран „сокл”, сиротиғски (На обали, 84-85).

(в) Анамезофора:

Реч је о другом страху, о оном тешко објашњивом страху невиних људских бића пред појавама овог света. Реч је о детињском страху, који - већ према томе какав је први додир тога детета са друштвом и његовим законима - или ишчезава доцније са годинама, са умним развитком и правилним васпитањем или, напротив, остаје у детету [...] (Кньга, 59).

Андрићево стваралаштво препознатљиво је по: (а) фигурама смисаоне дискурсне целине (епифонем, ентимем); (б) фигурама заснованим на амплификативним десцедентним конекторима (дистрибуција, регресија).

Од фигура смисаоне дискурсне целине у збирци Деца фреквентнији је епифонем јер се свет најчешће сагледава тако што се полази од посебног или појединачног да би се дошло до општег:

Цео живот оног првог света био је њиму и његовим друговима досадан, изгледао неважан и нестваран, а прави, главни и истински свет - била је кула са игром и доживљајима које само игра даје, и само у детињству, у доба када се живи животом својих жеља и тако доживљава све што се жели. А најдубље дечачке жеље, ношене маштом 
и незадржљивим снагама тела које се развија и расте, бирају често за своје поприште забачена, напуштена места и рушевине $(К у л а, ~ 8)$.

Ређи је обрнути начин сагледавања стварности, који полази од општег и долази до посебног или појединачног (ентимем). Тако, у следећем одломку постоје три сегмента - најпре се наводи појединачно искуство, које се затим уопштава, а на крају конкретизује:

И у сну сам испаштао своју чудну љубав за панораму. Али све су те дневне и ноћне муке и незгоде биле муке и незгоде дечачких година, а то значи: и тешке су и многобројне, и лако се подносе и не трају дуго. Сат-два тврдог спавања или зрачак јутарње светлости у стању су да их збришу све, без трага. И већ сутрадан сва моја пажња била је упућена на другу страну. Моје мисли испуњавала је радозналост за нов програм, а моје време одлазило је на трчкарање и довијање како да дођем до новца потребног за улазницу, до ког се тако тешко долази (Панорама, 137-138).

Код фигура заснованих на амплификативним десцедентним конекторима доминира дистрибуција, која подразумева да се прво наведе један општи појам у форми лексеме или субординативне конструкције, а да се онда тај појам конкретизује навођењем саставних делова:

За њега се време од раног пролећа до касне јесени делило на два неједнака дела. На једној страни, варош са грађанима и чаршијом, са школом, кућом и породицом, а на другој - кула (Кула, 8).

Шта је свет, стварни свет са живим људима и њиховим међусобним односима израженим у имању и сили и власти, у новцу и рачуну, а шта слика света са својим богатством, лепотом и радошћу? (Панорама, 140). 
У збирци Деца ређе се јавља регресија, која подразумева да се прво наводе два или више појмова у форми координативне конструкције, а да се онда о сваком појму посебно говори:

Понајчешће су се играли рата, подељени на Србе и Турке, или просто на наше и ваше, наоружани дрвеним мачевима, и штитовима и шлемовима од лима и картона. Једна војска би се испела на ивицу зида и ту се утврдила и сакрила под искрзаним остацима кровова, а друга би настојала да открије непријатеља, да се успуже уза зид и својом виком избаци скривеног противника из његовог положаја (Кула, 8).

Ефекат се појачава уколико интерферирају дистрибуција и регресија:

Tоп! У срећи постојань коју за мене значе ове слике, то је трагични акценат без којег, како изгледа, нема ни среће ни постојағь. Тај акценат казује да се свака срећа и свако nостојағе могу сваког трена претворити у нешто што је противно од њих, а то их чини несталним и - тако дивним и драгоценим (Панорама, 127).

Последња група текстостилема коју издвајамо у збирци Деца настаје употребом супститутивних речи (заменице и заменички прилози) у стилистичкој функцији. Употреба супститутивних речи у анафоричкој и катафоричкој функцији представља уобичајене (стилски неутралне) појаве у тексту. Међутим, граматичка анафора и граматичка катафора могу допринети стилогености израза:

To су, дакле, $\boldsymbol{m e}$ лепоте и $\boldsymbol{m a}$ задовољства која човека чекају кад стекне право да се служи библиотеком! (Книга, 65).

Раскош и лепота! То на овим обалама од камена и песка не ниче и не цвате. О том се машта. Па, ипак, у 
његовом сећању, јави се управо у том тренутку нешто што личи на то, слабо и бледо и само издалека, као снивано (На обали, 86).

И ко би смео да му сада приђе и понуди неку ниску и нечасну зараду? Човеку који је ово учинио од себе. Ко би могао помислити на $\boldsymbol{m o}$ ? Где је $\boldsymbol{m a}$ касаба и где су $\boldsymbol{m u}$ ситни људи који би му могли прићи са таквим понудама? Са овог обасјаног зида на ком он столује и доспева, ближи је и најдаљи чудесни град на далеком Истоку, са својим кулама, женама и подвизима, него ова шака просутих кућа на ушћу Дрине и Рзава (Мила и Прелаи, 31).

Први горенаведени пример (из приповетке Кюига) има наглашено иронично значење, што није карактеристика књижевности за децу, а иронија је појачана узвичном интонацијом. Заменицу у последњем примеру Андрић је у збирци означио курзивом (Човеку који је ово учинио од себе).

\section{2. Стилистичке разлике}

Сви претходно разматрани синтаксостилеми, семантостилеми и текстостилеми појављују се као стилистичке доминанте у збирци Дец, ако ово дело посматрамо као целину. Условно речено, густина и стилогеност свих типова стилема појачавају се од почетка књиге до приповетке На обали (седма по реду), у којој достижу кулминацију. Ова приповетка означава крај детињства и почетак суочавања са завичајем или одразом завичаја у себи.

Од приповетке Змија (осма по реду) као да се смањују густина и стилогеност доминантних стилематичких поступака. Зашто је тако? Вероватно су ови стилеми погодни за обликовање емоционалног микродискурса, тј. унутрашњег света дечака, што одликује приповетке 
о детињству: Кула, У завади са светом, Мила и Прелаи, Дец, Прозор, Кюига. С друге стране, мање су погодни за обликовање рефлексивног микродискурса, који читаоца очекује у претпоследњој приповеци, дванаестој по реду (Писмо из 1920. године). Након завршетка детињства, завичај добија коначне димензије, да би се оне најоштрије осветлиле и преиспитале у Писму из 1920. године. Међутим, то се није догодило неочекивано за читаоца јер је најављено у приповеткама На обали и Змија.

На тематско-мотивском плану првих шест приповедака (Кула, У завади са светом, Мила и Прелаи, Деца, Прозор, Кюига) - могу се посматрати као дела за децу. Приповетка На обали напушта дечји поглед на стварност, што се уочава у ироничном нијансирању сећања на детињство, а иронија није својствена књижевности за децу.

У приповеци Змија јунакиња, која је странац у Босни, сажето исказује о Босни све оно о чему је размишљао јунак приче На обали и што ће записати јунак приче Писмо из 1920. године - обојица рођени и одрасли у Босни:

Ја сам ти увек говорила колико ту има беде и дивљине, колико ружног и неисказаног јада. Увек сам ти говорила, увек. Па ипак, све је још горе и црње. То је страшно, страшно! (3мија, 117).

Радости ту нема, ни покрета ни новине, а живот без тога и није живот, него голо постојање, робовање животу (На обали, 85).

Ја нисам толико наиван да тражим у свету варош у којој нема мржње. Не, мени треба само место у коме ћу моћи живети и радити. Овде то не би могао (Писмо из 1920. године, 190).

Приповетка Писмо из 1920. године потпуно се удаљава од књижевности за децу, што на стилском плану показују бројни примери парадокса: 
Можда је ваша највећа несрећа баш у томе што и не слутите колико мржње има у вашим љубавима и заносима, традицијама и побожностима (Писмо из 1920. године, 186).

Између разних вера јазови су тако дубоки да само мржња успева понекад да их пређе (Писмо из 1920. године, 188).

Како се Писмо из 1920. године може укључити у збирку Деца на тематско-мотивском плану? Писмо из 1920. године може се повезати са приповеткама Кула (прва по реду) и Панорама (девета по реду), и то са одломцима у којима се говори о дечјем доживљају игре рата и о дечјем виђењу непријатеља:

Неслућено, несхватљиво огњено поље бола, отварало се пред Лазаром, и у том огњу у трен ока су изгореле све речи и сви појмови са којима је досад живео и са којима је малопре весело кренуо у дивну и безазлену битку. Тај пламен који је, полазећи од прстију, обухватио цело његово тело - то је рат; а тај невидљиви што бије без престанка и милосрђа - то је непријатељ. Прави рат и прави непријатељ. У том наглом открићу била је већа и тежа половина његовог бола (Кула, 9).

Увек постоји негде непријатељ, али кад се он појави, топови почињу, тако рећи, сами од себе да пуцају - и убијају (Панорама, 127).

Тако ваша љубав не тражи много дела, а ваша мржња прелази врло лако на дело. И своју рођену земљу ви волите, жарко волите, али на три-четири разна начина која се међу собом искључују, смртно мрзе и често сударају (Писмо из 1920. године, 187).

Макс Левенфелд у Писму из 1920. године, у оквиру рефлексивног дискурса, напуштајући форму нарације, још једном сагледава противуречности у души човека из Андрићеве Босне. У одрастању свих дечака, независно од 
поднебља, ратне игре представљају саставни део детињства, али код људи у Андрићевом завичају доживљај рата као дечје игре остаје вероватно дубоко урезан у свест и након детињства.

\section{4. Закључак}

Лингвостилистичка анализа показује следеће језичко-стилске одлике збирке приповедака Деца Ива Андрића: (1) да су микродискурси у приповеткама изразито смисаоно уоквирени и да функционишу као уже композиционе целине - као емоционално-наративни или рефлексивно-наративни микродискурси; (2) да се компактност микродискурса постиже на плану реченице и пасуса - синтаксостилемима, семантостилемима и текстостилемима.

У стилске доминанте на нивоу целе збирке спадају: (1) синтаксостилеми (осамостаљивање, интензификација); (2) семантостилеми са формом координативне конструкције (антитеза, таутологија, кумулација); (3) текстостилеми (фигуре смисаоне дискурсне целине; фигуре засноване на амплификативним десцедентним конекторима; понављања).

Велику заступљеност имају напоредне конструкције, које су на различите начине стилски маркиране: (a) одступањима на синтаксичком плану (осамостаљивање, интензификација); (б) одступањима на семантичком плану (антитеза, таутологија, кумулација); (в) обимом напоредног низа, тј. већим бројем координираних чланова (синатроизам). Начин на који се постиже стилогеност напоредних низова зависи од броја координираних чланова (да ли су бинарне или вишечлане конструкције).

Приповетке у збирци Деца уклапају се са осталим делима овог писца у јединствен поглед на свет, 
показујући да људске патње имају своју генезу. Прочитане у континуитету, ове приповетке на одређен начин обликују јединствену и поливалентну слику дечјег сазревања у Босни, током једног времена у њеној новијој историји. Међутим, збирка Деца може се читати и разумети без икакве представе о месту и времену пишчевог одрастања. Дакле, Андрић је збирком Деца успео да створи универзалну причу о детињству у завичају.

\section{Извор}

Андрић 1991: И. Андрић, Деца, Сабрана дела, Књ. 9, Београд: Просвета

\section{Литература}

Бабић 2002: М. Бабић, О исказу у загради, Српски језик, VII/12, Београд, 303-320.

Бабић 2008: М. Бабић, Унутарреченична екскламативност, Српски језик, XIII/1-2, Београд, 189-201.

Бабић 2012: М. Бабић, Међузависност начина именовања ликова и вриједносне тачке гледишта у Проклетој авлији Ива Андрића, Српски језик, XVII/1-2, Београд, 81-94.

Башчаревић 2008: С. Башчаревић, Андрић о деци и за децу (Осврт на приповетку Излет), у: Т. Росић (ур.), Кюижевност за деиу у науци настави, Јагодина: Факултет педагошких наука, 280-285.

Ђукић-Перишић 2012: Ж. Ђукић-Перишић, Писаи, и прича, Нови Сад: Академска књига.

Јовић 1975: D. Jović, Lingvostilističke analize, Beograd: Društvo za srpskohrvatski jezik i književnost.

Ковачевић 1998: М. Ковачевић, Стилске фигуре и кюижевни текст, Београд: Требник. 
Ковачевић 2013: М. Ковачевић, Андрићев језик и стил - врхунац Вуковог језика и стила, у: Српски писии у озрачју стилистике, Београд: Филип Вишњић, 11-35.

Ковачевић 2015a: М. Ковачевић, Дискурс једне пјесме Алека Вукадиновића у дискурсној анализи, у: Б. Мишић-Илић, В. Лопичић (ур.), Језик, књижевност, дискурс. Језичка истраживаға, Ниш: Филозофски факултет, 49-62.

Ковачевић 2015б: М. Ковачевић, Стилистика и граматика стилских фигура, Београд: Јасен.

Милинковић 2014: М. Милинковић, Историја српске књижевности за деиу и младе, Београд: Bookland.

Николић 2012: М. Николић, Стилистика синтаксичких конструкција у приповеци Свадба Ива Андрића, у: B. Tošović (ur.), Ivo Andrić - književnik i diplomata u sjeni dvaju svjetskih ratova (1925-1941), Grac: Institut za slavistiku, 513-526.

2011: J. Петковић, Синтаксички и стилистички аспект експресивне сегментације реченице у Андрићевом Ex Pontu, y: B. Tošović (ur.), Austrougarski period u životu i djelu Iva Andrića (1892-1922), Grac: Institut za slavistiku, 665-673.

Петровић, Милинковић 2007: Т. Петровић, М. Милинковић, Писии за деиу у младе, Пожега: Епоха.

Станојчић 1967: Ž. Stanojčić, Jezik i stil Iva Andrića, Beograd: Filološki fakultet.

Степанов 2011: S. Stepanov, Marginalije iz Andrićeve sintaksičke stilematike (u pripovetkama post/austrougarskog perioda, y: B. Tošović (ur.), Austrougarski period u životu i djelu Iva Andrića (1892-1922), Grac: Institut za slavistiku, 709-721. 
Milka V. Nikolić

\section{THE STYLISTIC CHARACTERISTICS OF IVO ANDRIĆ'S STORIES COLLECTION CHILDREN IN THE CONTEXT OF CHILDREN'S LITERATURE}

The paper discusses the language of the stories in Ivo Andrić's collection Children. The linguo-stylistic method is applied. The goal is to examine which stylistic methods unite the stories in the Children collection. From the perspective of thematic and motif-based structure, stories in the Children collection differ. The short stories The Tower and Children come closest to children's literature (they discuss groups of children in a specific way and depict the world through the eyes of a child). Similar are the stories The Window and The Book (they shed a light on typical childhood events), as as the stories In a Feud with the World and Mila and Prelac (they shed a light on the problems of growing up). From the perspective of thematic and motif-based structure, a story Letter from 1920 goes furthest from children's literature. The analysis shows two tendencies: (1) to break down and extend a sentence; (2) to achieve meaningful unity of a passage. These tendencies become apparent in a great presence of stylistic methods at the sentential and textual levels. Observed as a whole, the Children collection represents a story about growing up in a homeland, and Bosnia is a unique homeland, which remains in a person forever. Andrić succeeded in creating a universal story about childhood in a homeland.

Key words: Ivo Andrić, the collection of stories Children, children's literature, the linguo-stylistic methods, composition unities. 